\title{
ANALISIS PENERAPAN PRINSIP MENGENAL NASABAH (KNOW YOUR CUSTOMER/KYC) DALAM MENCEGAH PENCUCIAN UANG PADA BPR UTOMO MANUNGGAL SEJAHTERA LAMPUNG DI BANDAR LAMPUNG
}

\author{
Kuswarak $^{(1)}$, Reny Ayu Susandra ${ }^{(2)}$ \\ Fakultas Ekonomi Universitas Sang Bumi Ruwa Jurai \\ kuswarak@fe.saburai.ac.id,renyayu_susandra@gmail.com
}

\begin{abstract}
Abstrak. Prinsip Mengenal Nasabah (Know Your Customer) atau yang biasa disebut KYC merupakan prinsip yang diterapkan Bank untuk mengetahui identitas nasabah, memantau kegiatan transaksi nasabah termasuk pelaporan transaksi yang mencurigakan. Prinsip ini tidak hanya berguna untuk mendeteksi transaksi keuangan yang kemungkinan merupakan tindak pidana pencucian uang tetapi juga melindungi Bank dari berbagai resiko dalam berhubungan dengan nasabah. Penelitian ini bertujuan untuk Mengetahui penerapan Prinsip Mengenal Nasabah (Know Your Customer/KYC) dalam mencegah pencucian uang pada BPR Utomo Manunggal Sejahtera Lampung. Populasi yaitu seluruh Karyawan BPR Utomo Manunggal Sejahtera Lampung yang beralamat di Jln. Raden Intan No 93 Tanjung Karang Bandar Lampung, sampel dalam penelitian ini sebanyak 10 orang dengN menggunakan metode Deskriptif. Pengumpulan data dilakukan dengan menggunakan kuesioner, sedangkan analisis data yang digunakan dalam penilaian ini menggunakan Metode Kualitatif. Kendala-kendala yang dihadapi yaitu masyarakat yang belum memahamii dan menerima pemberlakuan Penerapan Prinsip Mengenal Nasabah dan adanya rasa khawatiran akan kehilangan nasabah apabila menerapkan Prinsip Mengenal Nasabah, adanya sikap kurang kooperatif dari pihak nasabah itu sendiri, dan belum tersosialisasikan dengan baik tentang adanya peraturan tentang Prinsip Mengenal Nasabah dalam masyaraka. Untuk efektifnya mencegah dan memberantas pencucian uang peneraan prinsip ini perlu adanya dukungan dan kerjasama dari pemerintah, Bank, dan masyarakat.
\end{abstract}

Kata kunci: Bank, Nasabah, KYC, Pencucian, Uang.

\section{PENDAHULUAN}

Secara umum Perbankan memiliki peran yang strategis karena fungsi utama perbankan sebagai penghimpun dan penyalur dana dari masyarakat dalam rangka menunjang perekonomian nasional. Dalam kehidupan perekonomian yang semakin terbuka dan berkembang cepat, dibutuhkan layanan jasa perbankan yang semakin luas, baik dan berkualitas. Sehubungan dengan hal tersebut diperlukan sistem perbankan yang sehat, efisien dan mampu bersaing dalam era globalisasi dan perdagangan bebas.

Dalam hal lembaga keuangan BPR (Bank Perkreditan Rakyat) yang kegiatan operasionalnya sangat terbatas, yaitu hanya memberikan pinjaman serta menghimpun dana dalam bentuk tabungan dan dalam bentuk deposito berjangka, namun demikian kapasitas dalam tanggung jawabnya sama dengan bank umum, dijelaskan dalam surat edaran Bank Indonesia nomor 27/5/UPPB disebutkan bahwa, bank wajib mengumumkan laporan keuangannya dalam waktu dan bentuk yang ditetapkan oleh Bank Indonesia. Dalam melakukan kegiatan operasionalnya, untuk mengelola risiko yang mungkin timbul maka BPR wajib menerapkan prinsip kehati-hatian yaitu yang terkenal dengan 5 (lima) C :

1. Capital artinya calon nasabah harus mempunyai modal yang telah tersedia untuk melakukan hubungan kerja atau dalam menggunakan jasa bank. 
2. Capacity artinya calon nasabah harus mempunyai kemampuan untuk mengembalikan hutangnya.

3. Character artinya calon nasabah harus mempunyai integritas tinggi (minimal mempunyai komitmen tinggi).

4. Colateral artinya calon nasabah harus mempunyai jaminan sebagai kepercayaan Bank apabila terjadi resiko dikemudian hari.

5. Condition artinya calon nasabah harus dalam kondisi minimal sehat, cakap, dalam melakukan hubungan dengan bank atau dengan menggunakan jasa Bank.

Disamping unsur 5C Bank Perkreditan Rakyat juga harus melaksanakan prinsip kehati-hatian yaitu dengan Penerapan Prinsip Mengenal Nasabah. Berkenaan dengan peraturan Bank Indonesia no. 5/23/PBI/2003 tanggal 23 Oktober 2003 dan Undang-Undang No.25 Tahun 2003 Tentang "Penerapan Prinsip Mengenal Nasabah"'(Know Your Customer Principles) bagi Bank Perkreditan Rakyat dan surat edaran Bank Indonesia No. 6/19/DPBPR tanggal 22 april 2004 tentang "Pedoman standar Penerapan Prinsip Mengenal Nasabah bagi Bank Perkreditan Rakyat".

Bank Perkreditan Rakyat sebagai salah satu lembaga Intermediasi keuangan diwajibkan untuk membuat suatu kebijakan dan produser penerapan prinsip mengenal nasabah, agar industri perbankan tidak digunakan sebagai sarana kejahatan pencucian uang.

Penerapan prinsip ini secara konsisten dapat meningkatkan kinerja BPR Utomo Manunggal Sejahtera Lampung. Dengan kata lain Penerapan Prinsip Mengenal Nasabah (KYCP) merupakan salah satu faktor penting selain faktor lainnya dalam penerapan Prudential Banking yang dipatok pemerintah sebagai pilar utama menuju terciptanya Perbankan Indonesia yang sehat, perlu untuk diterapkan secara konsisten dan koprehensif untuk mencegah praktek penggunaan indutri perbankan sebagai sarana atau sasaran kejahatan, baik dilakukan secara langsung maupun tidak langsung oleh pelaku kejahatan perorangan maupun sindikasi.

Dewasa ini perkembangan perekonomian dunia yang sangat pesat telah mengarah kepada terbentuknya ekonomi global. Demikan juga Indonesia mengalami perkembangan perekonomian seiring dengan berkembangnya globalisasi perdagangan dunia sebagai akibat semakin meningkatnya kebutuhan akan barang dan jasa serta terbukanya komunikasai internasional yang didukung dengan teknologi modern perkembangan tersebut mendorong munculnya beraneka ragam kegiatan bisnis terutama dibidang perbankan. Kegiatan pencucian uang mempunyai dampak yang serius terhadap stabilitas sistem keuangan maupun perekonomian secara keseluruhan.

Pencucian uang tersebut umumnya berasal dari kegiatan-kegiatan: korupsi, penguapan, narkotika, psikotropika, penculikan, penipuan, terorisme, pencurian, penggelapan, perjudian, prostitusi, pemalsuan uang, penyelindupan imigran, penyelundupan tenaga kerja, penyelundupan barang, perdagangan manusia, perdagangan senjata gelap, bidang perbankan, bidang pasar modal, bidang asuransi, bidang perpajakan, badang kehutanan, bidang kelautan, dsb.

Tujuan utama penerapan Prinsip Mengenal Nasabah (KYC) didunia perbankan adalah agar bank dapat mendeteksi secara dini adanya indikasi kegiatan transaksi yang melanggar hukum (ilegal) dari nasabahnya, sehingga Bank dapat dilindungi dari sasaran kegiatan pencucian uang. 
BPR Utomo Manunggal Sejahtera Lampung mencoba mengoptimalkan penerapan prinsip mengenal nasabah . BPR Utomo Manunggal Sejahtera Lampung adalah salah satu bank yang perkembangannya sangat pesat di Bandar Lampung, yang menawarkan jasa perbankan kepada pengusaha kecil, menengah, dan masyarakat lainnya yang membutuhkan jasa tersebut.

Aset BPR Utomo Manunggal Sejahtera Lampung hingga bulan maret tahun 2014 adalah Rp7 Triliun, Dana Pihak Ketiga capai Rp3,6 Triliun, pembiayaan Kredit Rp6 Triliun. Masing-masing perbandingan asset 19,9 persen, DPK 7,28 persen, dan Pembiayaan Kredit 21,6 persen,

Berdasarkan uraian di atas, maka peneliti bermaksud melakukan penelitian dengan judul: "Analisis Penerapan Prinsip Mengenal Nasabah (Know Your Customer/KYC) Pada BPR Utomo Manunggal Sejahtera Lampung”.

\section{KAJIAN TEORI}

\section{Pengertian Perbankan}

Menurut Prof. G.M. Verryn Stuart, Bank adalah badan usaha yang wujudnya memuaskan keperluan orang lain, dengan memberikan kredit berupa uang yang diterimanya dari orang lain, sekalipun dengan jalan mengeluarkan uang baru kertas atau logam. Jadi bank dalam hal ini telah melakukan operasi pasif dan aktif, yaitu mengumpulkan dana dari masyarakat yang kelebihan dana dan menyalurkan kredit kepada masyarakat yang membutuhkan dana.

Menurut Dr. B.N. Ajuha, Bank menyalurkan modal dari mereka yang tidak dapat menggunakan secara mengguntungkan kepada mereka yang dapat membuatnya lebih produktif untuk keuntungan masyarakat. Bank juga berarti saluran untuk menginvestasikan tabungan secara aman dan dengan tingkat suku bunga yang menarik. Menurut Kamus Indonesia Bank artinya uang (Prof. Drs. Wijowasito, 1980).

Menurut sejarah, Bank berasal dari kata banco yang artinya tempat duduk yang memanjang dan saat itu memang dipergunakan untuk tempat duduk. Sehingga banyak orang yang duduk di tempat itu, saat itu pula ada pemikiran orang atau sebagian orang, event itu digunakan untuk bertransaksi keuangan di banco-banco tersebut, akhirnya nama banco dijadikan nama - institusi atau lembaga keuangan di seluruh dunia yaitu yang bertittel Bank.

Menurut Undang-Undang Republik Indonesia nomor 10 tahun 1998 tentang Perbankan, Pasal 1. Perbankan adalah segala sesuatu yang menyangkut tentang bank, mencakup kelembagaan, kegiatan usaha, serta cara dan proses dalam melaksanakan kegiatannya. Sedangkan Bank adalah badan usaha yang menghimpun dana dari masyarakat dalam bentuk simpanan dan menyalurkan kepada masyarakat dalam bentuk kredit dan / atau bentuk-bentuk lainnya dalam rangka meningkatkan taraf hidup rakyat banyak.

\section{Penggolongan Bank}

Berdasarkan Jenisnya, Bank dibagi menjadi 2 (dua) yaitu Bank Umum Dan Bank Perkreditan Rakyat.

1. Bank Umum adalah Bank yang dapat memberikan jasa dalam lalu lintas pembayaran, dimana dalam pelaksanaan kegiatan usahanya dapat secara konvensional atau berdasarkan prinsip syariah. 
2. Bank Perkreditan Rakyat adalah Bank yang tidak memberikan jasa dalam lalu lintas pembayaran, yang dalam pelaksanaan kegiatan usahanya dapat secara konvensional atau berdasarkan prinsip syariah. Bank Perkreditan Rakyat menerima simpanan hanya dalam bentuk deposito berjangka, tabungan, dan / atau bentuk lainnya yang dipersamakan dengan itu.

Berdasarkan kepemilikannya, Bank dibagi menjadi 5 (lima) yaitu:

1. Bank milik Pemerintah

2. Bank milik Pemerintah Daerah

3. Bank milik Swasta Nasional

4. Bank milik Koperasi

5. Bank Asing atau Campuran.

Berdasarkan bentuk hukumnya, Bank dibagi menjadi 4 (empat) yaitu :

1. Bank berbentuk hukum perusahaan daerah

2. Bank berbentuk hukum perseroan (PERSERO)

3. Bank berbentuk hukum perseroan terbatas (PT)

4. Bank berbentuk hukum koperasi.

Berdasarkan kegiatan usahanya, Bank dibagi menjadi 2 (dua) yaitu :

1. Bank devisa

2. Bank bukan devisa.

Berdasarakan sistem pembayaran jasa, Bank dibagi menjadi 2 (dua) yaitu :

1. Bank berdasarkan pembayaran bunga

2. Bank berdasarkan pembayaran berupa pembagian hasil keuntungan (bank dengan prinsip syariah ).

Untuk mewujudkan tugas pokoknya, BPR dapat melakukan usaha berikut :

1. Menghimpun dana dari masyarakat dalam bentuk simpanan berupa giro, deposito berjangka, sertifikat deposito, tabungan, dan/atau bentuk lainnya yang dipersamakan dengan itu.

2. Memberikan kredit

3. Menyediakan pembiayaan bagi nasabah berdasarkan prinsip bagi hasil sesuai dengan ketentuan yang ditetapkan dalam peraturan pemerintah.

4. Menetapkan dana dalam bentuk Sertifikat Bank Indonesia (SBI), deposito berjangka, sertifikat deposito, dan/atau tabungan pada Bank lain.

Sedangkan usaha-usaha yang dilarang bagi BPR meliputi :

1. Menerima simpanan berupa giro dan ikut serta dalam lalu lintas pembayaran (LLP).

2. Melakukan kegiatan usaha dalam valuta asing, kecuali melakukan transaksi atau jual beli uang kertas asing.

3. Melakukan penyertaan modal.

4. Melakukan usaha perasuransian.

\section{Pengertian Pencucian Uang}

Pada saat ini, lebih dari sebelumnya, pencucian uang atau yang dalam istilah bahasa inggrisnya disebut money laundering. Sudah merupakan fenomena dunia dan merupakan tantangan bagi dunia internasional. Walaupun begitu tetap tidak ada definisi yang berlaku universal dan komprehensif mengenai apa yang disebut dengan pencucian uang atau money laundering.

Adapun beberapa definisi yang ada mengenai pencucian uang antara lain:

a. Sarah N.Welling mengemukakan bahwa : "money laundering is the process by which one conceals the existence, illegal sources, or illegal application of come, and than disguises that income to make it appear legitimate" (pencucian uang adalah suatu proses, dimana salah satu bentuknya dapat berupa sumber- 
sumber illegal atau penempatan secara ilegal kemudian menyamarkan pendapatan tersebut sehingga kelihatan sebagai oendapatan yang sah).

b. David Fraser mengemukakan bahwa : " money laundering is quite simply the process through which "dirty" money (proceeds of crime, is washed through "clean" or legitimate sources and enterprises so that the "bad guys" may more safely enjoy their ill'gotten gaibs" (proses sederhana dari uang koyor yang didapat dari tindak pidana, dicuci atau dimasukkan ke dalam sumber yang sah atau legal, sehingga pelaku tindak pidana dapat lebih aman menikmati keuntungan yang didapat dari kejahatan mereka).

c. Dalam Pasal 1 pasal 1 Undang-Undang Nomor 25 tahun 2003 tentang perubahan atas Undang-Undang Nomor 15 Tahun 2002 tentang Tindak Pidana Pencucian Uang, Pengertian Money Laundering Adalah: “ perbuatan menempatkan, mentransfer, membayarkan, membelanjakan, mengibahkan, menyumbangkan, menitipkan, membawa keluar negeri, menukarkan atau perbuatan lainnya atas harta kekayaan yang diketahuinya atau patut diduga merupakan hasil tindak pidana dengan maksud menyembunyikan, atau menyamarkan asal-usul harta kekayaan sehingga seolah-olah menjadi hata kekayaan yang sah".

Money laundering pada intinya melibakan asset yang disamarkan sehingga dapat dipergunakan tanpa terdeteksi bahwa asset tersebut berasal dari kegiatan yang illegal. Melalui money laundering, pendapatan yang berasal ari kegiatan yang melawan hokum diubah menjadi aset keuangan yang seolah-olah berasal dari sumber yang sah atau legal.

\section{METODE PENELITIAN}

\section{Objek Penelitian}

Dalam penelitian ini yang menjadi objeknya yaitu karyawan pada BPR Utomo Manunggal Sejahtera Lampung, yang beralamat di Jln. Raden Intan No 93 Tanjung Karang Bandar Lampung. Pelaksanaan penelitian mulai bulan Juni sampai Agustus 2016.

\section{Metode Penelitian}

Metode yang digunakan pada penelitian ini adalah penelitian deskriptif analisis. Deskriptif penelitian ini terbatas pada usaha mengungkapkan suatu masalah atau keadaan atau peristiwa sebagaimana adanya sehingga bersifat sekedar untuk mengungkapkan. Hasil penelitian ini memberikan gambaran secara obyektif tentang keadaan sebenarnya dari obyek yang diselidiki. penelitian yang bersifat deskriptif analisis bertujuan menggambarkan kenyataan-kenyataan yang ada atau realitas dan menggambarkan obyek yang menjadi pokok permasalahan.

\section{Teknik Pengumpulan Data}

Untuk mendapatkan dan mengumpulkan data yang sesuai dengan kebutuhsn dalam penelitian ini, maka metode pengumpulan data yang digunakan adalah sebagai berikut :

1. Data Primer

Data Primer adalah data yang diperoleh secara langsung dari responden dan narasumber tentang objek yang diteliti. Yaitu dengan wawancara langsung dengan Kabag di BPR Utomo Manunggal Sejahtera Lampung. 
2. Data Sekunder

Data sekunder yaitu data teoritis yang diperoleh melalui studi kepustakaan dimaksudkan untuk lebih menetapkan kebenaran data atau informasi yang diperoleh ditempat penelitian, sehingga kebenaran tulisan meiliki validitas yang tinggi.

Dalam penelitian ini, teknik pengumpulan data yang dilakukan adalah dengan cara :

1) Wawancara

Teknik ini dijalankan dengan nara sumber secara bebas terpimpin dengan melakukan tanta jawab oleh Kabag BPR Utomo Manunggal Sejahtera Lampung.

2) Studi Kepustakaan

Yaitu penelitian yang dilakukan dengan mengumpulkan data atau pendapat para ahli atau ilmuwan yang berhubungan denagn obyek yang diteliti, dari buku literature atau lainnya yang dapat mendukung peneliti dalam membahas masalah yang dihadapi.

3) Observasi

Teknik ini dilakukan dengan mengadakan pengamatan secara langsung terhadap obyek yang diteliti. Dalam hal ini peneliti terjun langsung ke Bank Perkreditan Rakyat yang bersangkutan.

4) Dokumentasi

Dokumentasi mengumpulkan dengan cara yang ada yang memiliki keterkaitan dengan penelitian yang sedang dilakukan.

\section{Teknik Sampel}

Populasi dalam penelitian ini adalah unit yang ada sangkut pautnya dengan tanggung jawab bank sebagai lembaga keuangan berkaitan dengan Peraturan Bank Indonesia No. 5/23/PBI/2003 yaitu seluruh karyawan pada bagian operasional BPR Utomo Manunggal Sejahtera Lampung J1 Raden Intan No 93 Tanjung Karang Bandar Lampung. Menurut Sugiyono (2004) Sampel merupakan bagian dari populasi yang menjadi sumber data dalam penelitian, yang mana sampel merupakan bagian dari jumlah karakteristik yang dimiliki oleh populasi. Menurut Arikunto (2010), apabila jumlah populasi lebih dari 100, maka diambil antara $10 \%-15 \%$ atau $20 \%-25$ $\%$ atau lebih.

\section{Metode Analisis}

Metode analisis yang digunakan dalam penelitian ini adalah Metode Kualitatif, karena data yang dikumpulkan hanya sedikit dan data tersebut tidak dapat diklasifikasikan.

Untuk menganalisa data yang bersifat kualitatif ini maka peneliti mempergunakan analisa kualitatif, yaitu data yang diperoleh dipilih dan disusun secara sistematis kemudian di analisa secara kualitatif untuk mendapatkan deskriptif tentang bagaimana Peraturan Bank Indonesia nomor 5/23/PBI/2003 Tentang Penerapan Prinsip Mengenal Nasabah Bagi Bank Perkreditan Rakyat ditempatkan pada penerapan yang proporsional.

Untuk melengkapi data di atas perlu melakukan wawancara langsung dengan 10 oarng yang dijadikan sebagai responden penelitian yang terdiri dari beberapa karyawan pada BPR Utomo Manunggal Sejahtera Lampung, antara lain:

1. Claudia Florensa selaku Kabag Oprasional

2. Fera selaku Kabag Customer Service

3. Yoanna Sunjaya selaku Teller

4. Mitra Itha Selaku Teller

5. Nona Nurulitha Selaku Teller

6. Intan Novianti Selaku Teller 
7. Kristian Selaku Customer Service

8. Fransiska selaku Customer Service

9. Frengki Selaku Customer Service

10. Alfiana Selaku Customer service.

\section{HASIL DAN PEMBAHASAN}

Pelaksanaan Peraturan Bank Indonesia nomor:5/23/PBI/2003 mengenai arti pentingnya Prinsip Mengenal Nasabah/KYC bagi BPR dalam mencegah pencucian uang maka, Menurut Claudia Florensa selaku Kabag Oprasional BPR Utomo Manunggal Sejahtera Lampung menyatakan bahwa dengan diberlakukan peraturan tersebut nasabahnya tidak merasa terganggu apabila ditanya perolehan sumber dananya, bahkan saat ada lembaga daerah yang menempatkan dananya juga ditulis sendiri sumbernya dari APBD dan sekaligus dijelaskan kegunaanya, juga ada dana dari Bank lain di pindahkan dananya dengan alasan klasik tentunya masalah bunga simpanan yang lebih tinggi dan data juga menunjukkan perkembangan yang signifikan, demikian pula dikuatkan oleh Fera selaku Kabag Customer Service yang menyatakan perkembangan simpanan masih menggembirakan nasabah masih mau mengisi data dengan sejujurnya dan lengkap hanya bebrapa saja ada yang tidak lengkap.

Menurut salah satu Teller yang bernama Yoanna Sunjaya setelah munculnya Peraturan Bank Indonesia nomor:5/23/PBI/2003 cukup lita jelaskan dan kita sosialisasikan sehingga masyarakat memahami, lebih spesifiknya nasabah telah maklum dan tidak ada kendala, tetapi ada juga terkadang nasabah yang tidak jujur menuliskan sumber dana dan tujuan transaksinya untuk apa hanya sebatas mngisi data saja tetapi tidak sesuai kebenarnanya.ini yang terkadang menjadi kendala. Pendapat salah satu Teller ini pun dienarkan oleh Claudia Florensa selaku
Kabag Oprasional di BPR Utomo Manunggal Sejahtera Lampung.

Untuk jawaban responden atau karyawan yang lainnya juga tidak berbeda dengan yang lainnya.

Berdasarkan hasil wawancara di atas dapat disimpulkan bahwan dengan melakukan Prinsip Mengenal Nasabah kita bisa mencegah pencucian uang, namun butuh sosialisasi agar nasabah mau memberikan informasi atau data yang lainya dengan jujur dan nasabah juga bias dengan nyaman menabung di BPR Utomo Manunggal Sejahtera lampung.

\section{KESIMPULAN}

\section{Kesimpulan}

Berdasarkan hasil penelitian dan pembahasan dapat disimpulkan bahwa Prinsip Mengenal Nasabah merupakan bagian yang tidak terpisahkan dari sistem pengendalian risiko BPR, maka BPR wajib menerapkan prinsip kehati-hatian yaitu 5C. Menurut Claudia Florensa selaku Kabag Oprasional di BPR Utomo Manunggal Sejahtera Lampung, "Dalam pelaksanaan penerapan prinsip mengenal nasabah BPR masih sedikit mengalami kendala yaitu dalam pengisian formulir, nasabah terkadang merasa tidak nyaman dan cendrung tidak jujur".

\section{Saran}

Upaya untuk mencegah pencucian uang bukanlah hal yang mudah. Perkembangan teknologi, komunikasi, informasi dan ilmu pengetahuan menjadikan kejahatan ini berkembang pula. Diperlukan keseriusan untuk mencegah pencucian uang yang dapat merusak sendisendi perekonomian bangsa. Adapun beberapa saran dalam upaya mencegah pencucian uang : 
1. Bank diharapkan lebih ekstra lagi dalam mensosialisasikan hal-hal yang berkaitan dengan Prinsip Mengenal Nasabah (Know Your Costumer) kepada calon nasabahnya.

2. Perlu adanya sosialisasi tentang Prinsip Mengenal Nasabah (Know Your Costumer) melalui media elektronik maupun media cetak, agar masyarakat calon nasabah mudah mengakses.

3. Perlu ditingkatkan upaya pengikutsertaan aspek komunikasi, yaitu kemampuan petugas Bank dalam mengkomunikasikan informasi seputar Prinsip Mengenal Nasabah yang diterapkan oleh Bank kepada calon nasabahnya.

4. Perlu adanya landasan hukum tentang Penerapan Prinsip Mengenal Nasabah yang jelas dan di atur sendiri dalam bentuk undang-undang.

\section{DAFTAR PUSTAKA}

Achmadi, Abu. 2002. Metodologi Penelitian. Jakarta: Bumi aksara.

Arikunto, Suharsimi. 2010. Prosedur Suatu penelitian Praktek. Jakarta: PT. Rieka Citra.

Bank Indonesia, Surat Edaran Bank Indonesia Nomor : 27/5/UPPB, 25 Januari 1995, Hal 2.

Bank Inonesia. 1999. Kumpulan Ketentuan Pelaksanaan di bidang Perbankan (Undang-undang Nomor 10 Tahun 1998). Semarang.

Bank Indonesia. 2008. Ayo ke Bank. TABUNGAN Bank Perkreditan Rakyat (BPR), Program Edukasi Masyarakat dalam Rangka
Implementasi

Arsitektur

Perbankan Indonesia (API).

Bank Indonesia, Peraturan Bank Indonesia Nomor : 5/23/PBI/2003 tentang Penerapan Prinsip Mengenal Nasabah (Know Your Customer Principles).

Hasibuan, Malayu S.P. 2008. Dasar-dasar Perbankan. Jakarta: Bumi aksara.

Siahaan, N.H.T. 2002. Pencucian Uang dan Kejahatan Perbankan, Cet.1. Jakarta: Pustaka harapan Sinar Harapan.

Sugiyono. 2004. Metode Penelitian Bisnis. CV. Bandung: Alfabeta.

Sjahdeini, Sutan Remy. 2003. Pencucian Uang. Jurnal Hukum Bisnis. Vol.22. No. 03. Pp 08.

Undang-undang Republik Indonesia Nomor 25 Tahun 2003. Tentang Tindak Pidana Pencucian Uang.

Undang-undang Republik Indonesia Nomor 8 Tahun 2010. Tentang Pencegahan Dan Pemberantasan Tindak Pidana Pencucian Uang (UU PPTPPU). 